\title{
Lead removal using Fallen Coffee Plant Leaves (FCPL) powder: Characterization, Equilibrium, Kinetics and Thermodynamic studies
}

\author{
$M$ Tukaram Bai ${ }^{*}$, Ch. I. A.Raju ${ }^{2}, V$ Sridevi $^{3}$, Nalluri Chittibabu ${ }^{4}$, and $P$ Venkateswarlu ${ }^{5}$ \\ ${ }^{1}$ Assistant Professor, Department of Chemical Engineering, AUCE (A), Andhra University, Visakhapatnam, India \\ ${ }^{2}$ Assistant Professor, Department of Chemical Engineering, AUCE (A), Andhra University, Visakhapatnam, India \\ ${ }^{3}$ Professor, Department of Chemical Engineering, AUCE (A), Andhra University, Visakhapatnam, India \\ ${ }^{4}$ Professor, Department of Chemical Engineering, AUCE (A), Andhra University, Visakhapatnam, India \\ ${ }^{5}$ Professor (Retired), Department of Chemical Engineering, AUCE (A), Andhra University, Visakhapatnam, India
}

\begin{abstract}
Biosorption of lead onto Fallen Coffee Plant leaves (FCPL) powder from an aqueous solution was studied in the present study. The characterization of FCPL powder was done by FTIR, XRD, SEM and BET. The equilibrium agitation time for lead biosorption is $60 \mathrm{~min}$. The optimum $\mathrm{pH}$ and dosage values are 5.2 and $20 \mathrm{~g} / \mathrm{L}$ respectively. In the range of variables studied, percentage biosorption is increased from 75.1 to $95.5 \%$. The maximum uptake capacity of $3.664 \mathrm{mg} / \mathrm{g}$ is obtained at $303 \mathrm{~K}$. In the present investigation the equilibrium data was well explained by Langmuir, Redlich-Peterson with a correlation coefficient of 0.99 , and followed by Temkin and Freundlich isotherms. The kinetic studies reveal that the biosorption system obeyed the pseudo second order kinetic model by considering the correlation coefficient value as 0.99 . From the values of $\Delta \mathrm{S}, \Delta \mathrm{H}$ and $\Delta \mathrm{G}$ it is observed that the biosorption of lead onto Fallen coffee plant leaves(FCPL) powder was irreversible, endothermic and spontaneous.
\end{abstract}

\section{Introduction}

All living organisms require heavy metals in low concentrations but high concentrations of heavy metals are toxic and can cause cancer [1]. Nowadays the environment is threatened by an increase in heavy metals. Therefore, in recent years, the removal of heavy metals has become an important issue [2]. Methods for removing metalions from aqueous solution mainly consist of physical, chemical and biological technologies. Conventional methods for the removal of heavy metal ions from wastewater, such as chemical precipitation, flocculation ,membrane filtration, ion exchange, and electro dialysis electrolysis, are often costly or ineffective for the treatment of low concentrations of pollutants [3]. Biological uptake is a promising approach that has been studied in the past decade. This process is a good candidate for replacing old methods[4].High efficiency, removal of all metals even at low concentrations, being economical, and energy independence are the main advantages of biological uptake which present this process as a viable new technology [5]. biosorption is used to describe the passive non- metabolically mediated process of metal binding to living or dead biomass[6]. Water pollution by heavy metals is globally recognized as an increasing environmental problem since the starting of the industrial revolution in 18th century [7]. Heavy metals are elements having atomic weight between 63.5 and
200.6, and a specific gravity greater than 5.0 [8].These metals may come from different sources such as electroplating, textile, smelting, mining, glass and ceramic industries as well as storage batteries, metal finishing, petroleum, fertilizer, pulp and paper industries .Lead is one of the industrial pollutants. Possibly enter to the ecosystem through soil, air, and water . Lead is the second element in the ranking of interest priority owing to its potential for causing brain damage to the central nervous system [9]. Lead can cause several unwanted effects, including disruption of the biosynthesis of hemoglobin, anemia, rise in blood pressure, kidney damage, subtle abortions, birth defects, disruption of nervous systems, brain damage, decline fertility of men through sperm damage, diminished learning abilities of children, abdominal pains, adrenal insufficiency, blindness, cardiovascular disease, Liver dysfunction, and a host of others diseases [10].The objective of the present work is to explore the potential of biosorption technique for the removal of lead from aqueous solutions using cheap and abundantly available based materials like Fallen coffee plant leaves(FCPL) powder. The experiments are carried out in a batch operation to understand the equilibrium studies, kinetics and thermodynamics of the biosorption.

\footnotetext{
* Corresponding author:drmtukarambai@gmail.com
} 


\section{Materials and Methods}

Fallen coffee plant leaves (FCPL) were collected from Chinthapalli, a rural area in Visakhapatnam (District), Andhra Pradesh. These leaves were washed repeatedly with distilled water to remove dust and impurities and were allowed to dry in sunlight until they became crispy and colorless. The dried leaves were crushed into fine powder by grinding in a mechanical grinder. The powder was sieved and the different size fractions (45, $53,75,150$ and $300 \mu \mathrm{m}$ ) were obtained. These powders were stored separately in air tight glass bottles for further use as biosorbent. The characterization of the biosorbent was done using spectrum GX (Perkin Elmer, USA) spectrophotometer from 400-4000 cm-1 with a resolution of $1 / \mathrm{cm}$ using four scans with back ground subtraction. XRD of biosorbent samples were obtained in X-Ray Diffractometer (Model: 2036E201; Rigaku, Ultima IV, Japan). The pretreated biosorbent samples were examined in Scanning Electron Microscope, JEOL, JSM-6610, JAPAN and electron probe micro analyzer. All the required solutions were prepared with analytical reagents and double-distilled water. $1.615 \mathrm{~g}$ of $99 \% \mathrm{~Pb}(\mathrm{NO} \neg 3) 2$ was dissolved in distilled water in $1 \mathrm{~L}$ volumetric flask up to the mark to obtain $1000 \mathrm{mg} / \mathrm{L}$ of lead stock solution. The procedures adopted to evaluate the effects of various parameters viz. agitation time (t), biosorbent size (dp), biosorbent dosage (w), $\mathrm{pH}$ of aqueous solution, initial concentration of lead in aqueous solution ( $\mathrm{C} 0$ ) and temperature of aqueous solution on biosorption of metal (lead) were explained below. The range of the parameters are compiled in Table-1

Table-1 Experimental conditions investigated for nickel

\begin{tabular}{|l|l|}
\hline $\begin{array}{l}\text { Parameters } \\
\text { investigated }\end{array}$ & Values investigated \\
\hline $\begin{array}{l}\text { Agitation time, } \\
\mathrm{t}, \mathrm{min}\end{array}$ & $1-180$ \\
\hline $\begin{array}{l}\text { Biosorbent size, } \\
\mathrm{d}_{\mathrm{p}}, \mu \mathrm{m}\end{array}$ & $45-300$ \\
\hline $\begin{array}{l}\text { Biosorbent dosage, } \\
\mathrm{w}, \mathrm{g} / \mathrm{L}\end{array}$ & $2-20$ \\
\hline $\begin{array}{l}\mathrm{pH} \text { of aqueous } \\
\text { solution }\end{array}$ & $1-8$ \\
\hline $\begin{array}{l}\text { Initial lead } \\
\text { concentration, } \mathrm{C}_{0}, \\
\text { mg/L }\end{array}$ & $5-150$ \\
\hline Temperature, $\mathrm{K}$ & $283-333$ \\
\hline
\end{tabular}

\section{Characterization of Fallen coffee plant leaves (FCPL) powder FTIR spectrum of untreated and lead treated Fallen coffee plant leaves (FCPL) powder:}

The FTIR spectra of untreated and lead treated Fallen coffee plant leaves (FCPL) powder are shown in figs. 1 (a) and 1 (b) respectively. The broad peaks[11-16] at $3439.48 \mathrm{~cm}^{-1}$ and $3335.05 \mathrm{~cm}^{-1}$ are attributed to the stretching vibration absorption band of $-\mathrm{OH}$ group. The peaks at $2939.65 \mathrm{~cm}^{-1}, 2931.11 \mathrm{~cm}^{-1}$ and $2916.29 \mathrm{~cm}^{-1}$ can be assigned to asymmetric $\mathrm{CH}_{2}$ groups. The stretching vibration of spectra at $2487.13 \mathrm{~cm}^{-1}$ is due to the broad and medium intensity caused by presence of $\mathrm{O}-\mathrm{H}$ group acids. The peaks at $1650.36 \mathrm{~cm}^{-1}$ and $1622.38 \mathrm{~cm}^{-1}$ show the presence of $-\mathrm{NH}$ group. The peaks at $1541.48 \mathrm{~cm}^{-1}$ and $1524.68 \mathrm{~cm}^{-1}$ may represent the $\mathrm{CC}$ stretching of aromatic rings of lignin. The peak at $1378.83 \mathrm{~cm}^{-1}$ is caused by the $\mathrm{O}-\mathrm{H}$ bending. For lead treated biosorbent, its FTIR spectrum shows that wave number and the intensity of some peaks are shifted and substantially lower than those of untreated biosorbent. For instance, the wave numbers are shifted from $2487.13 \mathrm{~cm}^{-1}, 894.99 \mathrm{~cm}^{-1}$ and $766.14 \mathrm{~cm}^{-1}$ to 2321.62 $\mathrm{cm}^{-1}, 823.00 \mathrm{~cm}^{-1}$ and $666.91 \mathrm{~cm}^{-1}$ respectively after lead biosorption. The peak that appeared at $2321.62 \mathrm{~cm}^{-1}$, denotes phosphate ester group, is not seen in native biomass. The spectrum shows the $\mathrm{C}-\mathrm{O}-\mathrm{SO}^{3}$ bands at $823 \mathrm{~cm}^{-1}$. The peaks at $1035 \mathrm{~cm}^{-1}$ and $1063 \mathrm{~cm}^{-1}$ have remained unaltered before and after biosorption. The above changes observed in FTIR spectra indicate the functional groups presented in Fallen coffee plant leaves(FCPL) powder such as hydroxyl, carboxyl and amino participate in biosorption of lead by surface complexation.

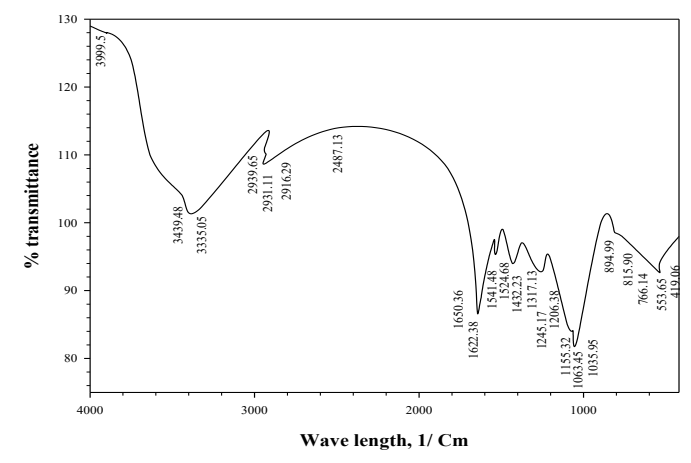

Fig: 1 (a) : FTIR image of beforetreating with lead

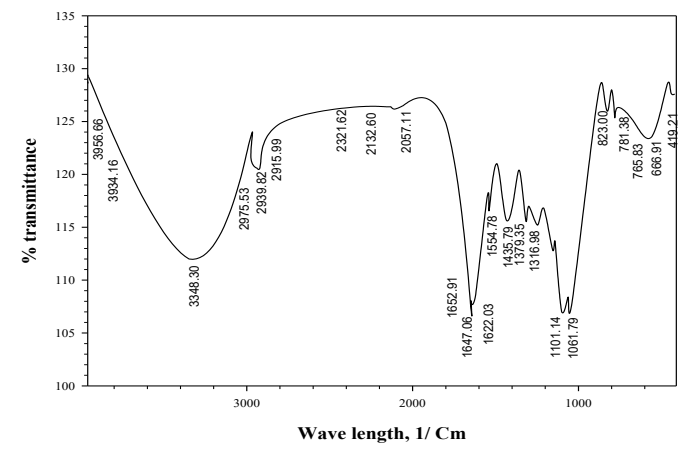

Fig: 1 (b) : FTIR image of after treating with lead

XRD pattern of the untreated and lead treated Fallen coffee plant leaves(FCPL) powder are shown in fig. 2 (a) and fig. 2 (b). These figs. illustrate the presence of a significant amount of amorphous material due to lignin and tannin in the sample. XRD patterns of Fallen coffee plant leaves (FCPL) powder before and after biosorption with lead indicate unaltered structure of Fallen coffee plant leaves(FCPL) powder.The SEM images of untreated and lead treated coffee powder are shown in 
figs 3 (a) and 3 (b) respectively. It is evident from images that the surface area is uneven, rough and heterogeneous with pores on the surface of the leaf powder before biosorption. SEM analysis after biosorption shows that the surface has irregular texture with globular and elongated grains over the surface of biosorbent. These elongated grains show that the lead particles are adhered onto the surface of leaf powder. The clustered grains like morphology, on treated biosorbent denote increased active surface area. BET analysis of Fallen coffee plant leaves (FCPL) powder that the surface area measured by BET method is 0.950 $\mathrm{m}^{2} / \mathrm{g}$ for $45 \mu \mathrm{m}$ size powder.

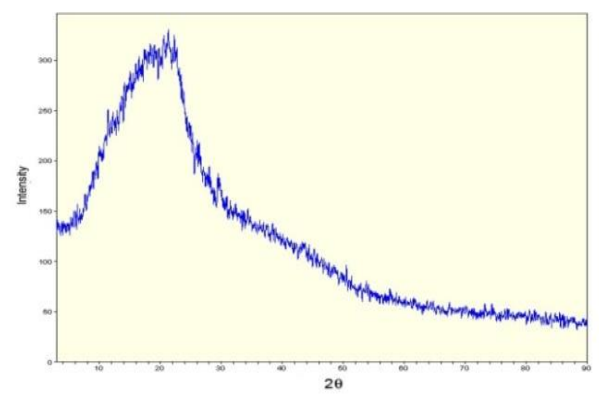

Fig. 2 (a) XRD of FCPL powder

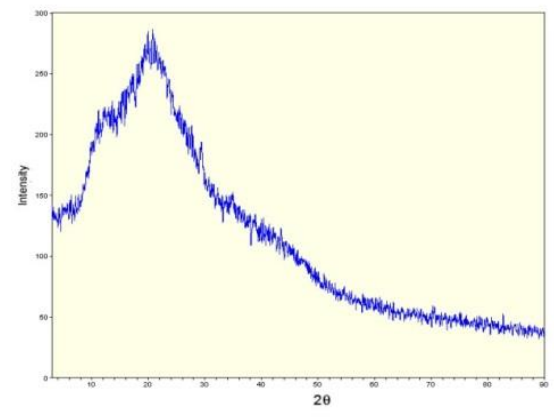

Fig.2 (b) XRD of lead treated FCPL powder

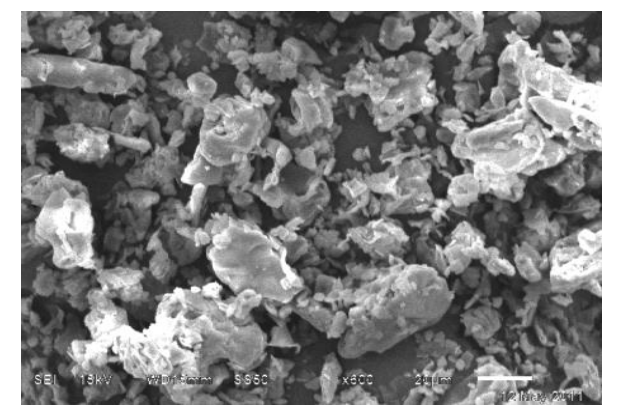

Fig.3(a) SEM image of untreated FCPL

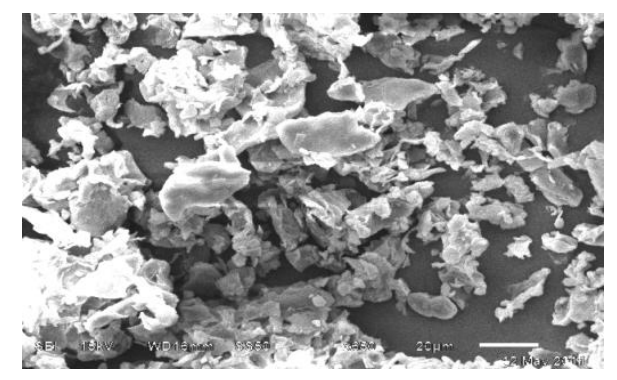

Fig.3(b) SEM image oftreated FCPL with lead

\section{Equilibrium studies:}

\subsection{Effect of agitation time, biosorbent size and dosage:}

The \% biosorption of lead is drawn against agitation time in fig. 4 for various ' $d_{p}$ ' values. $88.5 \%(0.84 \mathrm{mg} / \mathrm{g})$ of lead is biosorbed in the first $5 \mathrm{~min}$ due to the presence of $45 \mu \mathrm{m}$ size of $10 \mathrm{~g} / \mathrm{L}$ biosorbent. At the agitation time of $40 \mathrm{~min}$, the \% biosorption is increased to $90.18 \%$ $(0.867 \mathrm{mg} / \mathrm{g})$. From 40 to $60 \mathrm{~min}$. the percentage biosorption is marginal and gradually increased from $90.18 \%(0.867 \mathrm{mg} / \mathrm{g})$ to $91.00 \% \quad(0.865 \mathrm{mg} / \mathrm{g})$ respectively. After the agitation time of $60 \mathrm{~min}$, the \% biosorption of lead is constant indicating the attainment of equilibrium conditions[17-22]. To study the effect of biosorbent size, the experiments are carried out for various particle sizes of biosorbent $(45,53,75,150$ and $300 \mu \mathrm{m})$. The plot is shown in fig. 5 . The $\%$ biosorption of lead decreases from $91 \%(1.729 \mathrm{mg} / \mathrm{g})$ to $76.86 \%$ $(1.460 \mathrm{mg} / \mathrm{g})$ as the biosorbent size increases from 45 to $300 \mu \mathrm{m}$. With a decrease in the biosorbent size, surface area of the biosorbent decreases, there by the numbers of active sites available on the biosorbent are less exposed to the biosorbate. Fig. 6 shows the variation of $\%$ biosorption of lead with biosorbent dosage. As the biosorbent dosages increases from 2 to $20 \mathrm{~g} / \mathrm{L}, \%$ biosorption of lead has reached to $95.8 \%(0.91 \mathrm{mg} / \mathrm{g})$ from $83 \%(7.885 \mathrm{mg} / \mathrm{g})$. The change in $\%$ biosorption is minimal beyond the dosage of $20 \mathrm{~g} / \mathrm{L}$. The optimum biosorbent dosage of $20 \mathrm{~g} / \mathrm{L}$ is considered for studying the effects of other parameters.

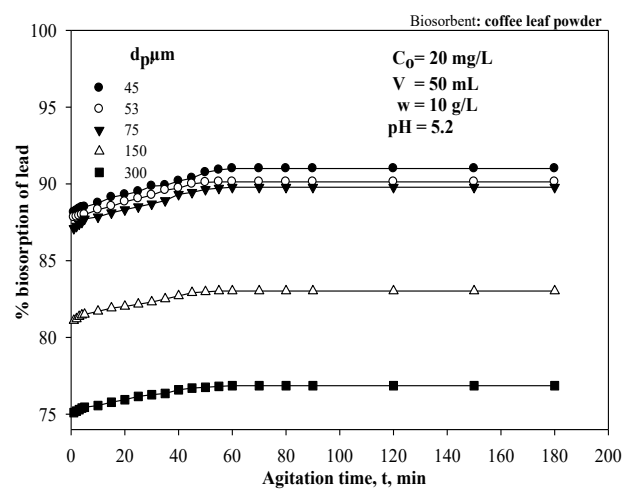

Fig.4 Effect of agitation time on \%biosorption of lead

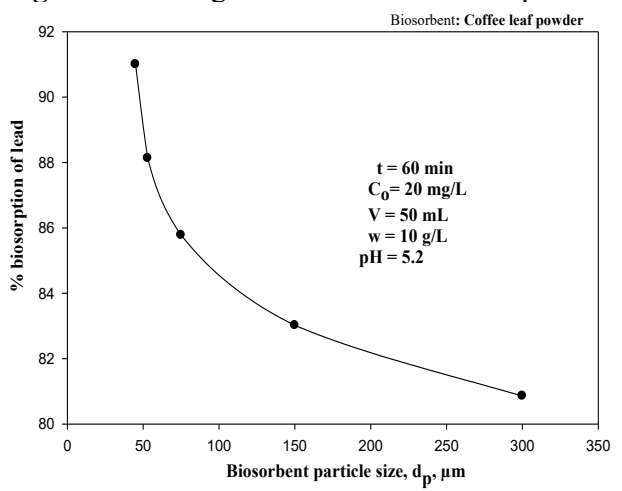

Fig.5 Effect of biosorbent size on \%biosorption of lead 


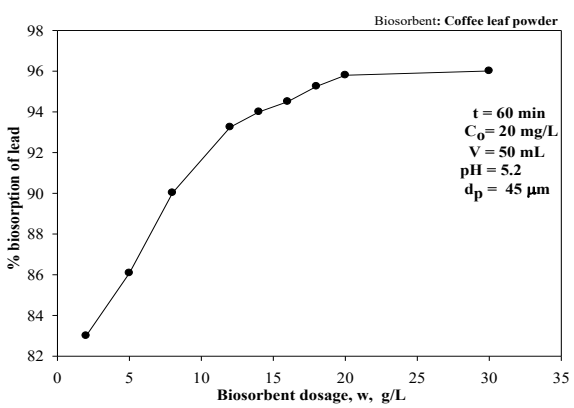

Fig.6 Variation of\%biosorption with biosorbent dosage

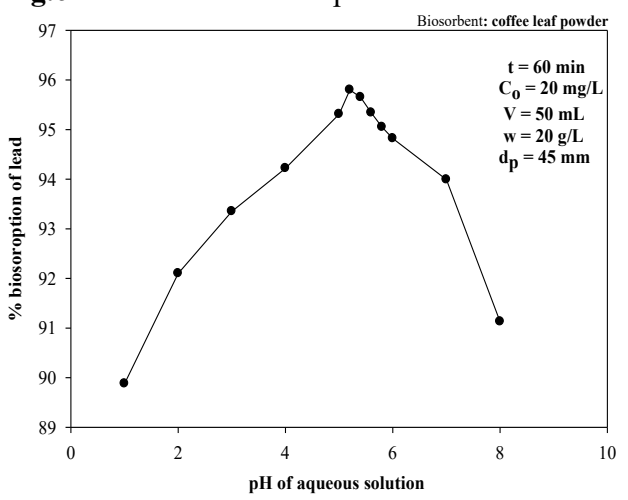

Fig. 7 Influence of $\mathrm{pH}$ of aqueous solution on \% biosorption

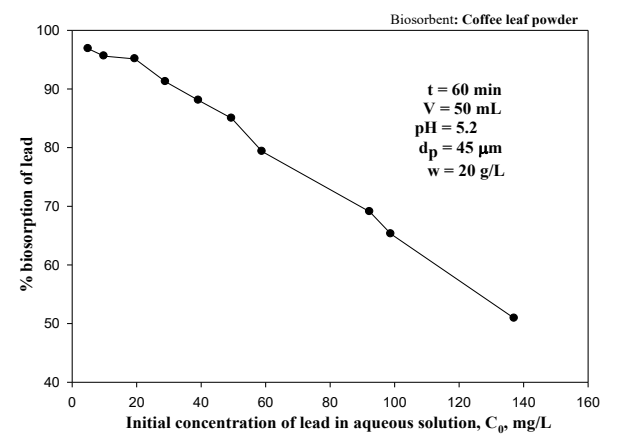

Fig.8 \% biosorption of lead as a function of initial concentration of lead in aqueous solutions.

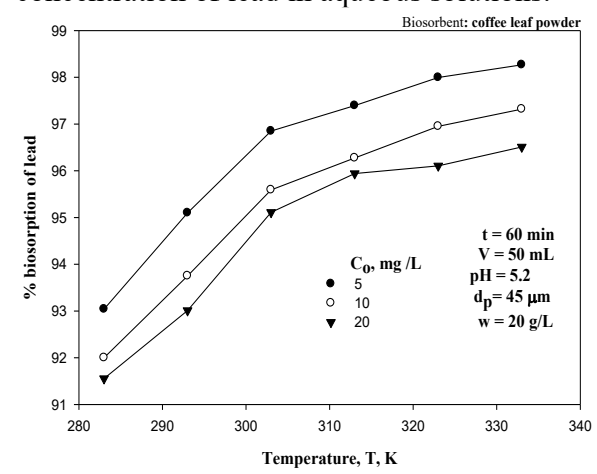

Fig.9 Effect of temperature on \% biosorption of lead

\subsection{Effect of $\mathrm{pH}$, initial concentration and Temperature of aqueous solution:}

The effect of $\mathrm{pH}$ is studied in the range of 1 to 8 . The $\%$ biosorption is increased from $89.88 \%(0.853 \mathrm{mg} / \mathrm{g})$ to $95.8 \%(0.910 \mathrm{mg} / \mathrm{g})$ when the $\mathrm{pH}$ of the aqueous solution is varied from 1 to 5.2 . The change in $\%$ biosorption is marginal in the $\mathrm{pH}$ range of 5 to 6 i.e., from $95.31 \%(0.905 \mathrm{mg} / \mathrm{g})$ to $94.82 \%(0.900 \mathrm{mg} / \mathrm{g})$. The graph between $\mathrm{pH}$ of the aqueous solution and \% biosorption of lead is shown in fig.7. At $\mathrm{pH}>6$, precipitation of lead might have occurred and resulted in decrease of $\%$ biosorption of lead onto Fallen coffee plant leaves(FCPL) powder upto $\mathrm{pH}$ of 8 . The presence of $-\mathrm{SO}_{3}$ stretching, $\mathrm{S}=\mathrm{O}$ and $\mathrm{C}-\mathrm{S}-\mathrm{O}$ bands, from ester sulphonate groups are very rich due to their ionexchange involvement in biosorption. The effect of initial concentration of lead in the aqueous solution on percentage biosorption of lead is shown in fig. 8. The percentage biosorption is decreased from $96.85 \%$ to $50.89 \%$ with an increase in initial concentration of lead in aqueous solution $\left(\mathrm{C}_{0}\right)$ from 5 to $150 \mathrm{mg} / \mathrm{L}$, while the uptake capacity is increased from 0.242 to $3.489 \mathrm{mg} / \mathrm{g}$. Such behavior can be attributed to the increase in the amount of biosorbate to the unchanging number of available active sites on the biosorbent. The decrease in the $\%$ biosorption of lead is marginal when the initial concentration is changed from $5 \mathrm{mg} / \mathrm{L}$ to $19 \mathrm{mg} / \mathrm{L}[23-$ 26]. Fig. 9 shows the effect of temperature on $\%$ biosorption of lead for different initial concentrations (5, 10 and $20 \mathrm{mg} / \mathrm{L}$ ). For an initial concentration of aqueous solution at $20 \mathrm{mg} / \mathrm{L}$, the $\%$ biosorption is increased from $91.55 \%$ to $96.51 \%$ as the temperature increases from $283 \mathrm{~K}$ to $333 \mathrm{~K}$. It indicated that the $\%$ biosorption of lead increases with an increase in temperature of aqueous solution.

\subsection{Isotherms}

The Freundlich, Langmuir, Temkin and RedlichPeterson isotherms [27-30] are shown in fig-10, Fig-11, fig.-12 and fig-13 correspondingly. The 'n' value from the above equation is 0.3247 . As ' $n$ ' value is less than one, it indicates favorable biosorption. The value of Freundlich constant $\left(\mathrm{K}_{\mathrm{f}}\right)$ is found to be $3.644 \mathrm{mg} / \mathrm{g}$. ). The maximum biosorption capacity $\left(\mathrm{q}_{\mathrm{m}}\right)$ of the Fallen coffee plant leaves (FCPL) powder for lead is 3.664 $\mathrm{mg} / \mathrm{g}$ by Langmuir isotherm at $303 \mathrm{~K}$ with good linearity (correlation coefficient, $\mathrm{R}^{2}=0.99$. The separation factor $\left(\mathrm{R}_{\mathrm{L}}\right)$ of 0.5047 shows favorable biosorption $\left(0<\mathrm{R}_{\mathrm{L}}<1\right.$. $A_{T}$ and $b_{T}$ values are 4.049 and 3992.9 respectively according to the linear form of Temkin isotherm and the linear plot is shown in fig.12. The resulting RedlichPeterson isotherm constant (B) and Redlich- Peterson isotherm exponent $(\mathrm{g})$ are $0.448 \mathrm{~L} / \mathrm{mg}$ and 0.8575 respectively. The correlation coefficient of 0.99 suggests that Redlich- Peterson isotherm model is well suited to describe the biosorption of lead onto the fallen coffee plant leaves (FCPL) powder. The Isotherm parameters for various isotherm models are compiled in table-2.

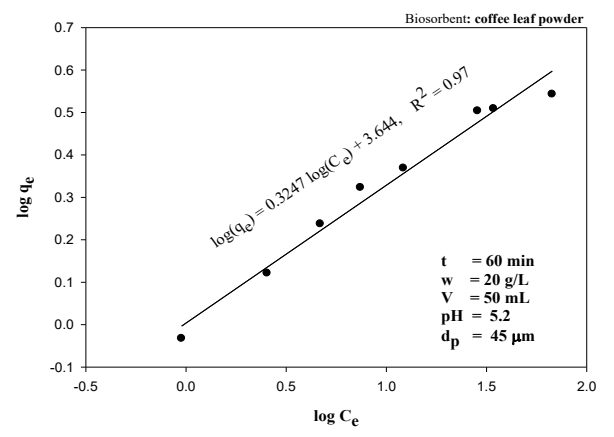

Fig.10 Freundlich isotherm for biosorption of lead 


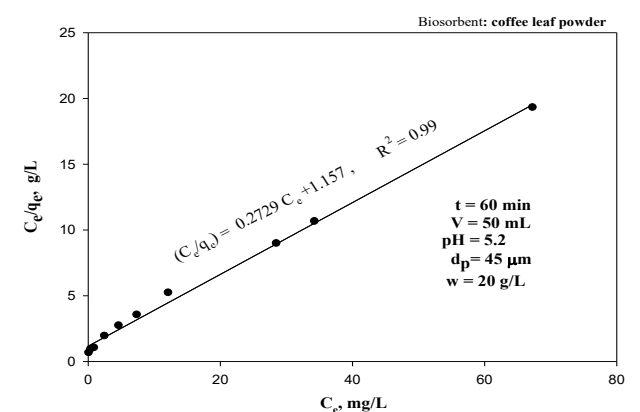

Fig.11 Langmuir isotherm for biosorption of lead

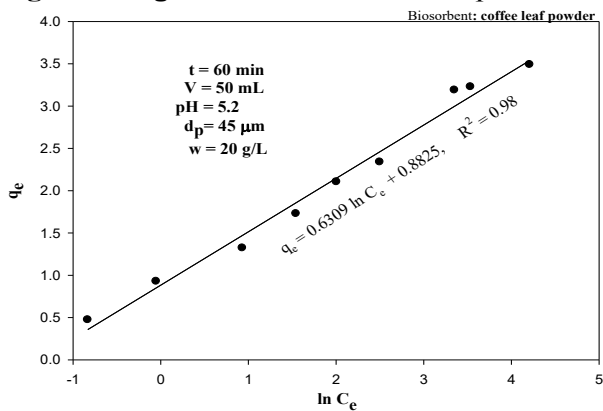

Fig.12 Temkin isotherm for biosorption of lead

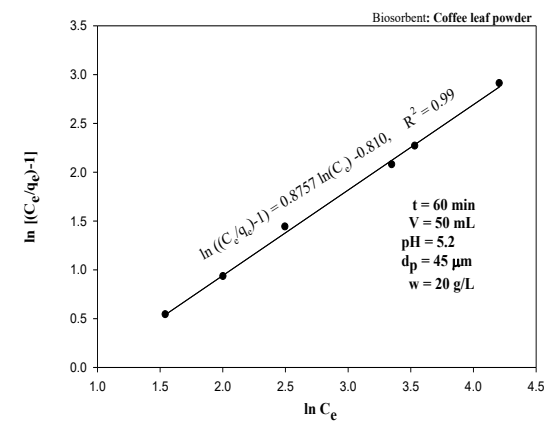

Fig.13 Redlich- Peterson isotherm for biosorption of lead

Table- 2: Isotherm parameters for various isotherm models

\begin{tabular}{|c|l|}
\hline & \\
\hline Freundlich & Constants \\
\hline $\log \mathrm{q}_{\mathrm{e}}=\log \mathrm{K}_{\mathrm{f}}+\mathrm{n} \log \mathrm{C}_{\mathrm{e}}$ & $\mathrm{K}_{\mathrm{f}}=3.644 \mathrm{mg} / \mathrm{g}$ \\
\hline $\log \mathrm{q}_{\mathrm{e}}=0.3247 \log \mathrm{C}_{\mathrm{e}}+3.644$ & $\mathrm{R}^{2}=0.97$ \\
\hline Langmuir & \\
\hline$\left(\mathrm{C}_{\mathrm{e}} / \mathrm{q}_{\mathrm{e}}\right)=1 /\left(\mathrm{bq}_{\max }\right)+\left(1 / \mathrm{q}_{\max }\right) \mathrm{C}_{\mathrm{e}}$ & $\mathrm{q}_{\mathrm{m}}=3.664 \mathrm{mg} / \mathrm{g}$ \\
\hline $\mathrm{C}_{\mathrm{e}} / \mathrm{q}_{\mathrm{e}}=0.2358 / \mathrm{C}_{\mathrm{e}}+1.157$ & $\mathrm{~b}=0.2358 \mathrm{~L} / \mathrm{mg}$ \\
\hline & $\mathrm{R}^{2}=0.99$ \\
\hline Temkin & \\
\hline $\mathrm{q}_{\mathrm{e}}=\left(\mathrm{RT} / \mathrm{b}_{\mathrm{T}}\right) \ln \left(\mathrm{A}_{\mathrm{T}}\right)+\left(\mathrm{RT} / \mathrm{b}_{\mathrm{T}}\right)$ & $\mathrm{A}_{\mathrm{T}}=4.049 \mathrm{~L} / \mathrm{mg}$ \\
$\ln \left(\mathrm{C}_{\mathrm{e}}\right)$ & $\mathrm{b}_{\mathrm{T}}=3992.9$ \\
\hline $\mathrm{q}_{\mathrm{e}}=0.6309 \ln \left(\mathrm{C}_{\mathrm{e}}\right)+0.8825$ & $\mathrm{R}^{2}=0.98$ \\
\hline Redlich- Peterson & \\
\hline $\ln \left(A \frac{C_{e}}{q_{e}}\right)=\mathrm{g} \ln \left(\mathrm{C}_{\mathrm{e}}\right)+\ln$ & $\mathrm{B}=0.448 \mathrm{~L} / \mathrm{mg}$ \\
\hline $\begin{array}{l}\ln \left(\left(\mathrm{C}_{\mathrm{e}} / \mathrm{q}_{\mathrm{e}}\right)-1\right)=0.8575 \ln \mathrm{C}_{\mathrm{e}}- \\
0.810\end{array}$ & $\mathrm{R}^{2}=0.99$ \\
\hline
\end{tabular}

In the present study, the kinetics is investigated with $50 \mathrm{~mL}$ of aqueous solution $\left(\mathrm{C}_{0}=18.5 \mathrm{mg} / \mathrm{L}\right)$ at $303 \mathrm{~K}$ with different biosorbent sizes in the interaction time intervals of 1 to $180 \mathrm{~min}$. Lagergren plot [31-35] of log $\left(\mathrm{q}_{\mathrm{e}}-\mathrm{q}_{\mathrm{t}}\right)$ vs. ' $\mathrm{t}$ ' is shown in fig. 14 and pseudo second order rate equation plot of $\left(\mathrm{t} / \mathrm{q}_{\mathrm{t}}\right)$ vs. ' $\mathrm{t}$ ' is drawn in fig.15. The resulting kinetic equations and rate constants are shown in table-3. As the correlation coefficient values for the pseudo second order kinetics are 0.99, the pseudo second order kinetics describes the mechanism of lead Fallen coffee plant leaves(FCPL) powder interactions better than first order kinetics $\left(\mathrm{R}^{2}=0.84\right)$.

Experiments are conducted to understand the biosorption behaviour with temperature from 283 to 323 K. The Van't Hoff's plots for the biosorption data obtained at various initial concentrations of the lead are shown in fig. 16. The values of $\Delta \mathrm{S}, \Delta \mathrm{G}$ and $\Delta \mathrm{H}$ obtained in the present investigation for different initial concentrations of lead are shown in table-4. In the present study, the enthalpy change is positive indicating that the biosorption is endothermic. The negative values of $\Delta \mathrm{G}$ indicate the feasibility of the process and spontaneous nature of biosorption and the positive values of $\Delta S$ reflect the affinity of Fallen coffee plant leaves(FCPL) powder for lead and show the increasing randomness at the solid/liquid interface during the sorption of lead ions on Fallen coffee plant leaves(FCPL) powder. In Table -4 Thermodynamic parameters for biosorption of lead by Fallen coffee plant leaves (FCPL) powder are compiled.

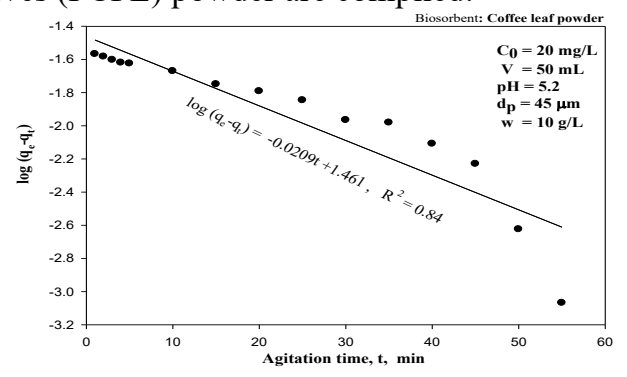

Fig.14 First order kinetics for the biosorption of lead

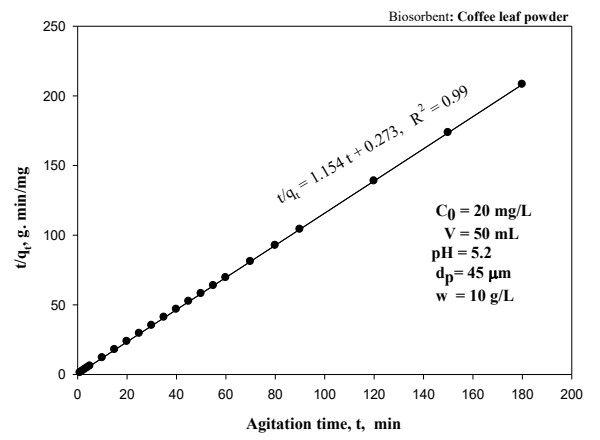

Fig.15 Second order kinetics

\section{Kinetics and Thermodynamics}




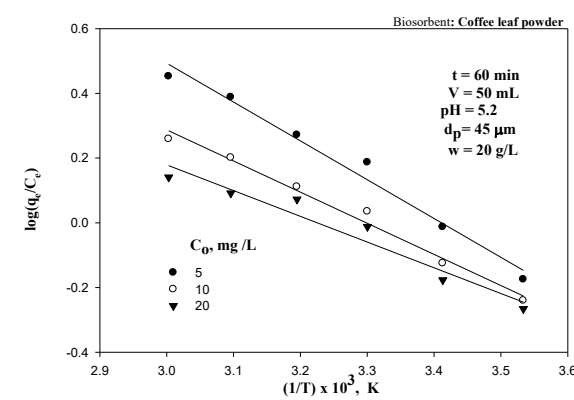

Fig. 16 Vant Hoff's plot

Table -4: Thermodynamic parameters for biosorption of

lead by Fallen coffee plant leaves(FCPL) powder

\begin{tabular}{|c|c|c|c|c|c|c|c|c|}
\hline \multirow[b]{2}{*}{$\begin{array}{l}\mathrm{C}_{0}, \\
\mathrm{mg} / \mathrm{L}\end{array}$} & \multirow[b]{2}{*}{$\begin{array}{l}\Delta \mathrm{S}, \\
\mathrm{J} / \mathrm{mol}- \\
\mathrm{K}\end{array}$} & \multirow{2}{*}{$\begin{array}{l}\Delta \mathrm{H}, \\
\mathrm{J} / \mathrm{mol}\end{array}$} & \multicolumn{6}{|c|}{$-(\Delta \mathrm{G}), \mathrm{kJ} / \mathrm{mol}$} \\
\hline & & & $\begin{array}{l}283 \\
\mathrm{~K}\end{array}$ & $\begin{array}{l}293 \\
K\end{array}$ & $\begin{array}{l}303 \\
\mathrm{~K}\end{array}$ & $\begin{array}{l}313 \\
\mathrm{~K}\end{array}$ & $\begin{array}{l}323 \\
\mathrm{~K}\end{array}$ & $3 \sqrt{3} 3 \mathrm{~K}$ \\
\hline 5 & 94.3 & 22.9 & 26.6 & 27.6 & 28.57 & 29.52 & 30.46 & $314_{40}$ \\
\hline 10 & 53.5 & 18.4 & 15.13 & 15.66 & 16.20 & 16.73 & 17.27 & 17580 \\
\hline 20 & 49.1 & 15.2 & 13.88 & 14.37 & 14.86 & 15.35 & 15.84 & $\begin{array}{c}16.33 \\
16 .\end{array}$ \\
\hline
\end{tabular}

\section{Conclusions}

Both experimental and theoretical studies are carried out for biosorption of lead from an aqueous solution using Fallen coffee plant leaves (FCPL) powder. The analysis of the experimental and theoretical data results in the following conclusions is Biosorption of lead onto Fallen coffee plant leaves(FCPL) powder is. The equilibrium agitation time for lead biosorption is 60 min. The optimum $\mathrm{pH}$ and dosage values are 5.2 and 20 $\mathrm{g} / \mathrm{L}$ respectively. In the range of variables studied, percentage biosorption is increased from 75.1 to 95.5 $\%$. The maximum uptake capacity of $3.664 \mathrm{mg} / \mathrm{g}$ is obtained at $303 \mathrm{~K}$. The kinetic studies show that the biosorption of lead is better described by pseudo second order kinetics $\left(\mathrm{K}_{2}=4.890 \mathrm{~g} /(\mathrm{mg}-\mathrm{min})\right)$. The biosorption is endothermic as $\Delta \mathrm{H}$ is positive. The biosorption is irreversible as $\Delta \mathrm{S}$ is positive. The biosorption is spontaneous as $\Delta \mathrm{G}$ is negative.

\section{References}

1. A.Cabuka, T. Akar, S.Tunali, S. Gedikli, Chemical Engineering Journal, 131293 (2007)

2. N. K. Amin, Desalination, 223,152 (2008).

3. A. Gundogdu, D. Ozdes, C. Duran, V. Numan Bulut, M. Soylak, H. B. Senturk, Chemical Engineering Journal, 153,62 (2009)

4. R.S. Bai, T.E. Abraham, Water Res 36, 1224 (2002)

5. B. Singha, S. K. Das, Colloids and surfaces B: Biointerfaces, 84, 221 (2011).

6. D. H. K.Reddy, K. Seshaiah, A.V.R. Reddy, M. M. Rao, M.C. Wang, Journal of Hazardous Materials, 174, 831 (2010)

7. Dàvila-Guzmàn N., Cerino-Cordova F., RangelMéndez J., Diaz-Flores P., AIChE Annual Meeting, Conference Proceedings, 1-9 (2011)
8. Duarte Zaragoza V., Carrillo R., Gutierrez Castorena C. Lead soption-desoprtion from organic residues, Environmental Technology, 32(2011) 353-361.

J. M. S. Pearce, Burton's Line in Lead Poisoning, European Neurology, 57, 118 (2007

9. D. Ozdes, A. Gundogdu, B. Kemer, C. Duran, H. B. Senturk, M. Soylak, journal of Hazardous material,166 1480 (2009).

10. F. Boudrahem, F. Aissani-Benissad, H. AitAmar, Journal of Environmental Management, 90, 3031 (2009)

11. F.Fu, Q. Wang, Journal of Environmental Management, 92, 407 (2010).

Gaballah, G. Kilbertus, Journal of Geochemical Exploration, 631 (1998)

H. M. F. Freundlich, Z. Phys. Chem., 57, 384 (1906)

H. Chen, J. zhao, G. Dai, J. Wu, H.Yan, Desallination, 262, 174 (2010)

P.Koedrith, H, Kim, J-I. Weon, Y.R. Seo, Int J Hyg Environ Health, 216, 587 (2013).

Langmuir, Journal of American Chemical Society,40, 1361 (1918).

17. L. Deng, Y. Su, H. Su, X. Wang, X. Zhu, Adsorption, 12, 267 (2006)

18. M. Iqbal, R.G.J. Edyvean, Minerals Engineering, 17, 217 (2004)

19. M. F. Sawalha, J. R. Peralta-Videa, J. R. Gonza'lez, M. D. Gardea, J. L. G. Torresdey, J. C chem. Thermodynamics, 39, 488 (2007).

20. M. R. Sangi, A. Shahmoradi, J.avad Zolgharnein, G. H. Azimi, M. Ghorbandoost, Journal of Hazardous Materials, 155, 513 (2008).

21. M. K. Mondal, Korean J. Chem. Eng., 27, 144 (2010)

22. M. Tuzen, A. Sari, Chemical Engineering Journal, 158, 200 (2010)

23. Nurbas, M. Nourbakhsh, S. Kilic, S. Ilhan, H. Ozdag, Chem Eng J, 85, 351 (2002)

24. T K Naiya, A K Bhattacharya, S K Das, Environmental Progress \& Sustainable Engineering, 28, 535 (2009).

25. O. Redlich, D. L. Peterson, J. Phys. Chem., 63, 1024 (1959)

26. O. D. Uluozlu, A. Sari, M. Tuzen, M.Soylak, Bioresource Technology, 99, 2972 (2008)

27. PX Pinto, SR Al-Abed, DJ Reisman, Chem Eng J 166,1002 (2011)

28. P. King, N. Rakesh, S. Beenalahari, Y. P. Kumar, V.S.R.K. Prasad, Journal of Hazardous Materials, 142, 340 (2007)

29. R. Nadeema, T. M. Ansari, A. M. Khalid, Journal of Hazardous Materials, 156, 64 (2008)

30. R. Han, Z. Lua, W. Zoua, W. Daotong, J. Shi, Y. Jiujun, Journal of Hazardous Materials, 137, 480 (2006)

31. N.Rangsayatorn, E.S.Upatham, M. Kruatrachue, P.Pokethitiyook, G.R. Lanza, Environmental Pollution, 119, 45 (2002)

32. S. Qaiser, A. R. Saleemi, M. Umar, Journal of Hazardous Materials, 166 ,998 (2009) 
33. S. T. Akar, A. Gorgulu, B. Anilan, Z. Kaynak, T. Akar, Journal of Hazardous Materials, 165, 126 (2009)

34. J Wang, C Chen, Biotechnol Adv 27:195

35. Z. Dan, G. Jianwei, Gao, Tingyan, Y. Yigao, C.Hong, Wuhan University Journal of Natural Sciences, 04-0755 (2007). 